\title{
Prevalence and incidence of the diagnosis of gout in Great Britain
}

\author{
W. J. C. CURRIE
}

From the Clinical Department, UK and Ireland Region, the Wellcome Foundation Ltd.

SUMMARY A study in gout of the incidence of diagnosis from 1971 to 1975 and of the prevalence at 31 December 1975 was carried out in a representative general practice sample comprising 64 practices and a population numbering 1 in 145 of the total population of Great Britain. The results show an annual incidence in Great Britain from 1971 to 1975 varying from 0.25 to 0.35 per 1000 and an overall prevalence at 31 December 1975 of 2.6 per 1000 . The prevalence in England was found to be significantly greater than in the rest of Great Britain and that in Wales to be significantly greater than in Scotland. In $10 \%$ of the cases the gout was believed to be secondary, with induction by diuretics being the most frequent cause. The prevalence of primary gout was estimated to be $2 \cdot 3$ per 1000 .

Little has been published on the frequency of the diagnosis of gouty arthritis in Great Britain. Kellgren et al. (1953) found 6 cases covering a 5year period in a population of 3515 people, which is a prevalence of 1.7 per 1000 from the random sample of the population of Leigh in Yorkshire. Popert and Hewitt (1962) detected no one with this diagnosis in the rural area of Wensleydale. During the year 1970-1 the Royal College of General Practitioners carried out a survey (Office of Population Censuses and Surveys, 1974) which estimated the number of episodes of gout in England and Wales to be 1.8 per 1000 for that year. In addition, from a literature search Kellgren (1964) estimated the prevalence to be less than 3 per 1000 of the population of Europe and North America. Other studies had found similar results with 3 per 1000 in Western Europe (Lawrence, 1960) and $2 \cdot 8$ per 1000 in the United States (Wyngaarden and Fredrickson, 1960), though a result of 15 per 1000 has been found in the group of people followed up in the Framingham study (Hall et al., 1967).

Garrod (1876) raised the question of regional variation by stating that gout was less common in Scotland than England, and, although there are no recorded data, it is a frequently repeated belief (Traut, 1952). Certainly it is established that the prevalence of gout is much higher in some communities than others. The study by Lennane $e t$

Accepted for publication 1 May 1978

Correspondence to DrW. J. C. Currie, Department of Clinical Research, Merck, Sharp and Dohme, Hoddesdon, Herts. al. (1960) in Roturua showed a prevalence in New Zealanders of European stock of 3 per 1000 , while in the Maoris dwelling in the same town it was 27 per 1000 .

\section{Methods and materials}

Mainly owing to the efforts of the Royal College of General Practitioners a growing number of practices keep $\mathrm{E}$ books or some other form of diagnostic index of their patients. A practice without a diagnostic index for coding gout would have to rely heavily on the memory powers of its practitioners and ancillary staff for a list of previously made diagnoses. In view of the vagaries of human memory, it was felt preferable to base the study on actual records. Consequently, random sampling as a selection process was ruled out. It was therefore decided to enlist the help of a group of practices which could provide appropriate records and which would be representative of general practice within Great Britain.

At first contact with each practice the aims of the study were explained and a check was made on the following: (1) The keeping of a diagnostic index; (2) the keeping of an age/sex register; (3) the number of principals in the practice; (4) the practice designation-urban, rural, or mixed; (5) the year of graduation of each doctor with patients in the practice. A list was compiled of all practices stating that they kept a diagnostic index. This was followed up by ascertaining the date when each of these practices 
began coding gout and whether or not the doctors in each practice were reasonably certain that all such diagnoses had been coded in their diagnostic index. On obtaining satisfactory answers to these 2 questions, the practice was placed on a list from which the final selection was taken.

So that the sample would be of reasonable size it was decided that the total population of the practices selected should not be less than 1 in 200 of the total population of England, Wales, and Scotland respectively. The selection of specific practices was primarily based on whether the practice was designated urban, rural, or mixed, and secondly on the number of principals in the practice. In the hope of achieving a representative sample in England, Wales, and Scotland every attempt was made to match the frequency of each of the subgroups in both measurements against the national picture as published for England (Department of Health and Social Security, 1974) and provided by the DHSS (unpublished data for 1973) for Wales and by the Information Services Division (unpublished data for 1973) for Scotland. Selection was influenced also by an effort to ensure that the geographical location of the practices reflected the population densities of Great Britain. Although not influencing selection, the year of graduation of participating practitioners was monitored in the hope that it would reflect the national profile of this measurement. For the year of graduation the sample was compared with the official national figures from the DHSS for England and Wales and for Scotland as referred to above. Likewise, a watch was kept on the age/sex breakdown of the sample population by comparing it to the national profile (Population Projections, 1976), since it would be possible to match the above measurements, yet have a preponderance of practices with an abnormally high paediatric or geriatric population which could markedly affect the incidence and prevalence figures.

At this point pilot studies were conducted and firm commitments of participation were sought from the general practitioners.

Since the study was set up to assess the incidence and prevalence with which gout was being diagnosed in the community, a definition of gout was not stipulated at the beginning of the programme. It was felt that this could bias the returns from the doctors. Nevertheless, it was necessary to know what each doctor in the study defined as gout. This information $\Rightarrow$ was obtained by collecting the basis on which each of 602 gout diagnoses were made (Currie, 1979). From? a separate attitudinal survey conducted at the same $\frac{\overline{0}}{\bar{D}}$ time further information was obtained on the diagnostic criteria used by these doctors.

All statistical analyses have been carried out by the chi-squared test with a correction for discrete distributions (Yates's correction).

\section{Results}

Over a period of 17 months a total of 146 practices ${ }_{\infty}^{\omega}$ were contacted. In the final analysis 4 practicesiv failed to reply and 3 refused to co-operate. $(64 \vec{\circ}$ were unable to do so and 11 which were prepared to help were not utilised. These 11 practices were in areas already well represented and their inclusiondid not improve the representativeness of the totato profile). 63 practices with suitable diagnostic recording systems and which agreed to participate $\overrightarrow{0}$ were enlisted. An additional practice of approxi-e mately 800 patients, in a stable population area, which did not have a suitable gout recording system agreed to help. Since the doctor was well acquainted with the 800 patients and their records it was felt fair to incorporate this practice, thus making a8 total of 64 practices.

Table 1 defines the practice population size, its? ratio to the total population, the number of practices involved, and the number of participating principals within these practices. Because of the smaller size of the Scottish and Welsh populations than that of England a relatively larger sample was taken in the former 2 countries. While the total practice popu? lation size was 374832 , in relation to the age and sex analyses (Table 2) the total population was 258 091, which excluded 8 practices which did nof have an age/sex register and 78752 under 15-year olds from the remaining 56 practices. There were an additional 41 principals within these practices whose patients were not included.

Because of the way in which national statistic sల are kept it was necessary to compare the number of doctors rather than the actual number of practices

Table 1 Profile of population sample

\begin{tabular}{|c|c|c|c|c|c|}
\hline Location & $\begin{array}{l}\text { (1) Practice } \\
\text { population }\end{array}$ & $\begin{array}{l}\text { (2) National } \\
\text { population } \times 10^{6} \\
(1973)\end{array}$ & Ratio of (I) to (2) & No. of GPS & No. of practices \\
\hline $\begin{array}{l}\text { Great Britain } \\
\text { England } \\
\text { Wales } \\
\text { Scotland }\end{array}$ & $\begin{array}{r}374832 \\
259001 \\
40526 \\
75305\end{array}$ & $\begin{array}{r}54 \cdot 386 \\
46 \cdot 425 \\
2 \cdot 749 \\
5 \cdot 212\end{array}$ & $\begin{array}{l}1: 145 \\
1: 179 \\
1: 68 \\
1: 69\end{array}$ & $\begin{array}{r}160 \\
101 \\
22 \\
37\end{array}$ & $\begin{array}{r}64 \\
45 \\
7 \\
12\end{array}$ \\
\hline
\end{tabular}


Table 21975 prevalence rates per 1000 subdivided by sex and age*

\begin{tabular}{|c|c|c|c|c|c|c|c|c|c|}
\hline \multirow[t]{2}{*}{ Region } & \multicolumn{4}{|l|}{ Males } & \multicolumn{4}{|l|}{ Females } & \multirow{2}{*}{$\begin{array}{l}M / F \\
\text { prevalence } \\
\text { ratio }\end{array}$} \\
\hline & All $15+$ & $15-44$ & $45-64$ & $65+$ & All $15+$ & $15-44$ & $45-64$ & $65+$ & \\
\hline Great Britain & $6 \cdot 1$ & $1 \cdot 7$ & $10 \cdot 6$ & $12 \cdot 2$ & $1 \cdot 0$ & $0 \cdot 1$ & $1 \cdot 3$ & $3 \cdot 0$ & $6 \cdot 1 / 1$ \\
\hline $\begin{array}{l}\text { England } \\
\text { Wales } \\
\text { Scotland }\end{array}$ & $\begin{array}{l}7 \cdot 3 \\
5 \cdot 2 \\
2 \cdot 8\end{array}$ & $\begin{array}{l}2 \cdot 0 \\
1 \cdot 7 \\
0 \cdot 9\end{array}$ & $\begin{array}{r}12.5 \\
10.9 \\
4.7\end{array}$ & $\begin{array}{r}14 \cdot 8 \\
6 \cdot 2 \\
6 \cdot 8\end{array}$ & $\begin{array}{l}1 \cdot 3 \\
0 \cdot 5 \\
0 \cdot 7\end{array}$ & $\begin{array}{l}0 \cdot 1 \\
0 \cdot 1 \\
0 \cdot 1\end{array}$ & $\begin{array}{l}1 \cdot 7 \\
0 \cdot 2 \\
0.7\end{array}$ & $\begin{array}{l}3 \cdot 5 \\
1 \cdot 8 \\
2 \cdot 2\end{array}$ & $\begin{array}{r}5 \cdot 6 / 1 \\
10 \cdot 4 / 1 \\
4 / 1\end{array}$ \\
\hline
\end{tabular}

* From 15 years of age onwards.

for the urban, rural, mixed comparison. For this purpose it was necessary to use the total complement of 201 practitioners within the 64 practices rather than using only the 160 whose patients were included in the study.

By the chi-squared test the urban/rural/mixed split (Table 3) gave a good fit for Wales and Scotland, but showed there to be slightly too many of the mixed grade in the English practices. By the same test the split over size of practice (Table 4) showed a good fit for each of the 3 countries, but for Great Britain as a whole the practices with 4 or more principals were over represented (chi squared test at $1 \%$ level). The check on the doctors by year of graduation showed a similar profile to the National Health Service statistics with the exception of Scotland, where the sample had too many younger doctors (Table 5). Monitoring of the age/sex profile of the sample population confirmed that for both sexes the percentage of the sample that fell into each of the 4 age groupings (0-14 years, 15-44 years, 45-64 years, and 65 years and over) was exactly the same for the sample population as for the nation as a whole.

Table 3 Percentage of principals by practice designation (urban, rural, mixed)

\begin{tabular}{|c|c|c|c|c|c|c|c|c|}
\hline \multirow[t]{2}{*}{ Designation } & \multicolumn{2}{|c|}{ Great Britain } & \multicolumn{2}{|l|}{ England } & \multicolumn{2}{|l|}{ Wales } & \multicolumn{2}{|l|}{ Scotland } \\
\hline & $\frac{1}{\%}$ of 201 & \% of 23968 & $\%$ of 131 & $\stackrel{2}{\%}$ of 19997 & $\%$ of 25 & $\%$ of 1272 & $l^{l}$ of 45 & $\frac{2}{\%}$ of 2699 \\
\hline $\begin{array}{l}\text { Urban } \\
\text { Rural } \\
\text { Mixed }\end{array}$ & $\begin{array}{l}69 \\
20 \\
11\end{array}$ & $\begin{array}{r}74 \\
21 \\
5\end{array}$ & $\begin{array}{r}69 \\
24 \\
7\end{array}$ & $\begin{array}{r}76 \\
22 \\
2\end{array}$ & $\begin{array}{r}76 \\
20 \\
4\end{array}$ & $\begin{array}{r}63 \\
36 \\
1\end{array}$ & $\begin{array}{r}65 \\
9 \\
26\end{array}$ & $\begin{array}{l}66 \\
12 \\
22\end{array}$ \\
\hline
\end{tabular}

The number in each subgroup are expressed as a percentage of the total practitioners stated at the top of each column. Columns 1 relate to the study group and column 2 to the official national data.

Table 4 Ratio of single-handed, small, and large group practices

\begin{tabular}{|c|c|c|c|c|c|c|c|c|}
\hline \multirow[t]{2}{*}{ Number of principals } & \multicolumn{2}{|c|}{ Great Britain } & \multicolumn{2}{|l|}{ England } & \multicolumn{2}{|l|}{ Wales } & \multicolumn{2}{|l|}{ Scotland } \\
\hline & $\begin{array}{l}1 \\
\% \text { of } 64\end{array}$ & $\frac{2}{\%}$ of 10,803 & $\%$ of 45 & $\%$ of 9,039 & $\begin{array}{l}l \\
\% \text { of } 7\end{array}$ & $\frac{2}{\%}$ of 549 & \% of 12 & $\stackrel{2}{\%}$ of 1,216 \\
\hline $\begin{array}{l}1 \\
2 \text { or } 3 \\
4 \text { or more }\end{array}$ & $\begin{array}{l}30 \\
39 \\
30\end{array}$ & $\begin{array}{l}40 \\
43 \\
17\end{array}$ & $\begin{array}{l}33 \\
36 \\
31\end{array}$ & $\begin{array}{l}41 \\
42 \\
17\end{array}$ & $\begin{array}{l}29 \\
29 \\
42\end{array}$ & $\begin{array}{l}34 \\
49 \\
17\end{array}$ & $\begin{array}{l}15 \\
58 \\
25\end{array}$ & $\begin{array}{l}49 \\
44 \\
15\end{array}$ \\
\hline
\end{tabular}

Numbers in each subgroup are expressed as a percentage (\%) of the total practices in that country given at top of each column. both for the study group (column 1) and the official national data (column 2).

Table 5 Year of graduation

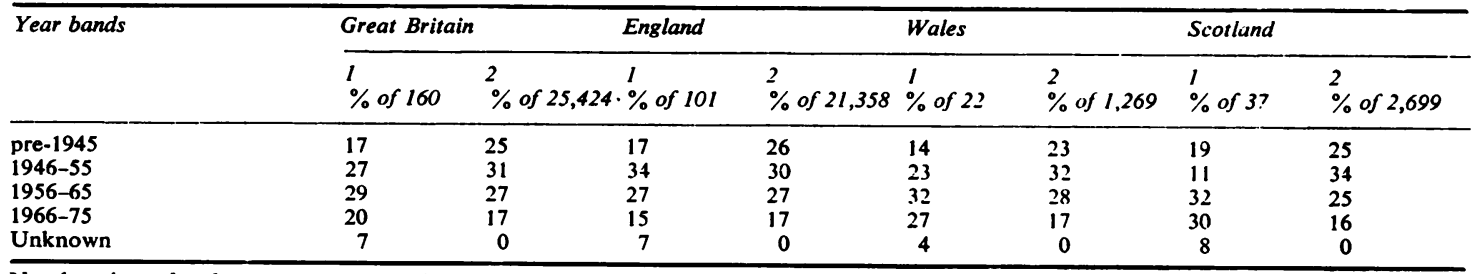

Numbers in each subgroup are expressed as a percentage (\%) of total doctors in that country quoted at the top of each column, both for the study group (Column 1) and the official national data (Column 2). 
Based on 966 diagnosed patients with gout who were alive and resident within the sample being studied on the December 31,1975, the prevalence in Great Britain was estimated to be 2.6 per 1000 . Of these 966 cases $97(10 \%)$ were considered to be secondary gout. This gave a prevalence for primary gout of $2 \cdot 3$ per 1000 if we include the $7 \%$ of cases where the doctor was uncertain but where there was no obvious reason to believe that secondary gout was present. The prevalence results (Table 6) showed England to have a significantly greater prevalence than the rest of Great Britain (chi-squared test at $0.1 \%$ level) and Wales to have a significantly greater prevalence than Scotland (chi-squared test at $1 \%$ level). The results for each region within England showed considerable variation, with the prevalence in the North being less than that in the South. Peak prevalence was recorded in the West Midlands and East Anglia, the difference from the other English regions being highly significant at the $0.1 \%$ level.

By the chi-squared test a significant difference was noted when the incidence results for 1971-2 were compared with those for 1974-5 for the total English results (at the $5 \%$ level) and for the West Midlands results (at the $1 \%$ level). For the other English regions, for Scotland, Wales, and Great Britain as a whole the differences in incidences quoted (Table 6) were not found to be significant.

The prevalence figures subdivided by age and sex (Table 2) for males showed that there were significantly more diagnoses of gout in the 15-44 year subgroup in England than in Wales plus Scotland (5\% level) and that in the 45-64 year subgroup there were significantly more in England plus Wales than in Scotland $(0.1 \%$ level). In the over-65-year age subgroup diagnoses were significantly greater $(0.1 \%$ level $)$ in England than Wales plus Scotland. For all males the diagnosis of gout was found significantly more often in England than Wales and in Wales than Scotland. Nevertheless this result must be taken guardedly as it is statistically not: independent of the above results. For females in the 45-64 year subgroup the prevalence in England waso greater than that in Wales plus Scotland (at $1 \%$ 음 level).

It became evident from both the basis of diagnosis in the 602 cases studied and from the attitudinalo survey that, almost invariably, gout represented ${ }^{\text {es }}$ a deposition of sodium urate in or around a jointo resulting in an episode of acute gouty arthritis or anacute extra-articular episode such as bursitis. In $9 \mathrm{\omega}$ cases the diagnosis was first made on the finding of a tophus. In each of these cases the patient subse $-\frac{0}{\omega}$ quently developed an acute arthritis during theo period of the survey. In 3 additional cases the diag $N$ nosis was made in patients who had a renal stone and a raised serum uric acid plus or minus a familyo history of gout. These 3 cases have been excluded from the entire gout survey, as were 5 other cases which had not experienced an acute gouty articular extra-articular episode, thus giving the group auniform basis of diagnosis.

\section{Discussion}

It was decided to recruit practices which, as a group would have a designation (urban, rural, mixedf and a size (single-handed small group, large group practice) profile that would be in proportion to tha $\overrightarrow{5}$ within general practice in Great Britain. In view oß the primary requirement that the practices had to record gout diagnoses and that their geographica $\overrightarrow{\mathrm{P}}$. locations should reflect the population densityo patterns for the UK it was found impossible to obtain a perfect fit. With the exception of the English mixed practices subgroup and the 4 or more prin cipal practices for Great Britain as a total, the 2 measurements used in practice selection compare favourably with the national figures (Tables 3 and 4)?

Table 6 Incidence and prevalence of the diagnosis gout

\begin{tabular}{|c|c|c|c|c|c|c|}
\hline \multirow[t]{2}{*}{ Region } & \multicolumn{5}{|c|}{ Incidence per 1000} & \multirow{2}{*}{$\begin{array}{l}\text { Prevalence } \\
\text { per } 1000 \\
1975\end{array}$} \\
\hline & 1971 & 1972 & 1973 & 1974 & 1975 & \\
\hline $\begin{array}{l}\text { Great Britain } \\
\text { Scotland } \\
\text { Wales } \\
\text { England } \\
\text { North } \\
\text { North-west } \\
\text { Yorkshire and }\end{array}$ & $\begin{array}{l}0.26 \\
0.12 \\
0.36 \\
0.29 \\
0.26 \\
0.26\end{array}$ & $\begin{array}{l}0.25 \\
0.16 \\
0.26 \\
0.27 \\
0.26 \\
0.18\end{array}$ & $\begin{array}{l}0 \cdot 33 \\
0 \cdot 17 \\
0 \cdot 13 \\
0 \cdot 41 \\
0 \cdot 49 \\
0 \cdot 07\end{array}$ & $\begin{array}{l}0.35 \\
0 \cdot 27 \\
0.25 \\
0.39 \\
0 \cdot 16 \\
0.29\end{array}$ & $\begin{array}{l}0 \cdot 30 \\
0 \cdot 17 \\
0 \cdot 17 \\
0 \cdot 35 \\
0 \cdot 35 \\
0 \cdot 32\end{array}$ & $\begin{array}{l}2 \cdot 6 \\
1 \cdot 3 \\
2 \cdot 1 \\
3 \cdot 0 \\
2 \cdot 7 \\
1 \cdot 6\end{array}$ \\
\hline $\begin{array}{l}\text { Humberside } \\
\text { East Midlands } \\
\text { West Midlands } \\
\text { East Anglia } \\
\text { South-east } \\
\text { South-west }\end{array}$ & $\begin{array}{l}0.09 \\
0 \cdot 23 \\
0 \cdot 35 \\
0 \cdot 53 \\
0 \cdot 27 \\
0 \cdot 38\end{array}$ & $\begin{array}{l}0.28 \\
0.29 \\
0.39 \\
0.54 \\
0.17 \\
0.43\end{array}$ & $\begin{array}{l}0.37 \\
0.36 \\
0.69 \\
0.45 \\
0.42 \\
0.26\end{array}$ & $\begin{array}{l}0.16 \\
0.32 \\
1.02 \\
0.18 \\
0.26 \\
0.45\end{array}$ & $\begin{array}{l}0.56 \\
0.17 \\
0.71 \\
0.00 \\
0.30 \\
0.16\end{array}$ & $\begin{array}{l}2 \cdot 9 \\
2 \cdot 3 \\
5 \cdot 6 \\
4 \cdot 8 \\
2 \cdot 2 \\
3 \cdot 6\end{array}$ \\
\hline
\end{tabular}


In addition, the measurement of doctors participating by year of graduation when compared with the national picture provided a good fit with the exception of the younger doctors in Scotland, who were in excess of the national picture (Table 5). The year of graduation is not recorded in the official statistics, but the date of birth of each doctor is. For purposes of calculating year of graduation the general rule of assuming graduation at 25 years of age was adopted.

Since certain areas, such as some new towns, have a predominantly young community, while other areas are favoured for retirement, it would be possible for the age/sex structure of the sample not to reflect that of the total population while giving a good fit for the practice and doctor parameters measured. Since the occurrence of gout increases with age, this comparison was deemed important. In the event it provided an excellent fit. Thus the sample was chosen by 2 practice parameters and checked by 2 separate measurements, one involving the doctors and the other the patients. In view of the results it is believed that the sample can be accepted as reasonably, but not totally representative. Since overwhelmingly, doctors equated gout with gouty arthritis, it was felt justifiable to remove the 8 cases which had not experienced acute articular or extraarticular (e.g., bursitis) episodes and thus create a group which was, in that respect, uniform in diagnosis.

The prevalence of the diagnosis of gout in Great Britain was shown to be $2 \cdot 6$ per 1000 population, which is in keeping with estimates covering Europe and North America (Lawrence, 1960; Wyngaarden and Fredrickson, 1960; Kellgren, 1964). Nevertheless the prevalence results are out of step with the Framingham findings (Hall et al., 1967). On admission to the Framingham study the patients were all in a limited age band of 30-59 years, and at the time of the report in 1967 the mean age was 58 years. The prevalence rates in the over-45-year-old groups for both sexes in this study might be considered a fairer comparison, but even these fall short of the USA results. The male to female prevalence ratio in the Framingham report was 7:1 while in the present study it was found to be $6 \cdot 1: 1$. The results (Table 6) of the study show a striking difference in the prevalence of the diagnosis of gout in the 3 countries, with Scotland being the lowest at $1 \cdot 3$ per 1000 of the study population and England the greatest at 3.0 per 1000 of the study population. Thus the pronouncement of Garrod (1876) and the time-honoured but unproved belief of many physicians since then seems to have been confirmed. Or has it?

That there is a striking difference in the frequency of the diagnosis being made in the 3 countries has been shown, but this is not of necessity the same as the frequency of the disease. However, while most ailments will be both over- and underdiagnosed during the practice of medicine, an examination of the diagnostic pattern (Currie, 1979) and the clinical profile (Currie, 1978) of the gout patients in each of the 3 countries yielded no statistical support for a significant degree of underdiagnosis in Scotland or overdiagnosis in England. Furthermore, a survey by Currie (in preparation) among the doctors in all 3 countries showed no obvious difference in attitude to the diagnosis of gout.

It has been noted from population studies in different parts of the world that the frequency of gout and the degree of hyperuricaemia in a community tend to occur somewhat hand in hand (Bremner and Lawrence, 1966). Therefore it is interesting to note that 2 recent studies (Sturge et al., 1977; Currie, in preparation) have shown no difference in the mean serum uric acid levels of population samples covering England, Wales, and Scotland. Nevertheless, it must equally be stated that the occurrence of clinical gout requires more than just a raised serum uric acid.

No doubt a number of factors are at play in creating the prevalence differences noted, and in this context it is worth remembering that gout has been shown to favour the higher social classes (Popert and Hewitt, 1962; Grahame and Scott, 1970; Currie, 1978). A statistical examination (chisquared with Yates's correction) of the Economic Activity Tables for Great Britain (Census, 1976) shows that there is a larger proportion of the Scottish community in classes 3,4 , and 5 than in England and Wales (significant at the $0.1 \%$ level). Thus gout should be less prevalent in Scotland, although it is doubtful if this could explain the total difference. However, another factor is worthy of comment in this context. The World Health Organisation's Statistics (1976) show the mortality rate from ischaemic heart disease to be greater in Scotland than in England and Wales. By use of the chisquared test with Yates's correction this difference, for both males and females, is found to be significant at the $0.1 \%$ level. This is by no means new since, Howe (1963) commented on the striking difference between the north and south of Great Britain in the mortality from ischaemic heart disease. Gertler and co-workers (1951) were first to note a statistically significant association of hyperuricaemia and coronary heart disease, and although more recent studies, such as the Framingham Study (Hall et al., 1967) suggest that hyperuricaemia is not a risk factor in ischaemic heart disease, the excess of deaths from ischaemic heart disease within Scotland 
might selectively reduce the pool of hyperuricaemic potential gout cases in that country.

As would be expected, the incidence of this diagnosis being made in each of the years from 1971 to 1975 in each of the 3 countries varies in line with the prevalence. One factor regarding the incidence figures is that they are relatively high in comparison to the prevalence results, being related by a factor of less than 10. The phenomenon has previously been noted in epidemiological studies (Rose, 1968).

Of the 966 cases $10 \%$ were considered to be secondary gout with diuretic therapy being the most frequent causal agent.

The results of the various regions of England show much variation, with the frequency of the diagnosis occurring more often in the south than in the north and with a peak in the west midlands. Since no attempt was made to ensure that the sample in every region of England was representative of that area, these results should be interpreted with more caution than those for the whole of England.

In both sexes (Table 2), the prevalence is seen to increase with age, and it is interesting to note that while gout is infrequent in men below 45 years old thereafter the diagnosis occurs in excess of $1 \%$ of the male community. The prevalence in the male is greater at all ages than in the female sex, but it is worth noting that after 44 years the rate of increase of the prevalence in females is considerably greater than in the male-no doubt related to the onset of the menopause with its associated rise in serum uric acid to levels approaching or equal to those in the male (Mikkelsen et al., 1965). While this is a fairly consistent pattern in all 3 countries, the diagnosis of gout in Welsh females is less than elsewhere, with a resultant higher male to female ratio. Therefore, either the ladies of Wales have some special protection from this malady, or their doctors are less inclined than their English and Scottish counterparts to make the diagnosis in the female sex.

I am indebted to the Royal College of General Practitioners and to many doctors in general practice for unselfishly making this project possible.

\section{References}

Bremner, J. M., and Lawrence, J. S. (1966). Population studies of serum uric acid. Proceedings of the Royal Society of Medicine, 59, 319-325.

Census (1971). Great Britain. (1976). Economic Activity Tables, Part IV, Table 29, (10\% sample). HMSO: London.
Currie, W. J. C. (1978). The gout patient in gensral practice. Rheumatology and Rehabilitation, 17, 205-218.

Currie, W. J. C. (1979). Diagnosis of gout in general practic Current Medical and Research Opinion (in press).

Department of Health and Social Security. (1974). Heal and Personal Social Services Statistics for England, 197. HMSO: London.

Garrod, A. B. (1876). A Treatise on Gout and Rheumat Gout (Rheumatoid Arthritis), 3rd edn., p. 218. Longmans్
Green: London.

Gertler, M. M., Garn, S. M., and Levine, S. A. (1951) Serum uric acid in relation to age and physique in health and in coronary heart disease. Annals of Internal Medicine 34, 1421-1431.

Grahame, R., and Scott, J. T. (1970). Clinical survey of $35 \mathrm{~s}$ patients with gout. Annals of the Rheumatic Diseases, 2\%

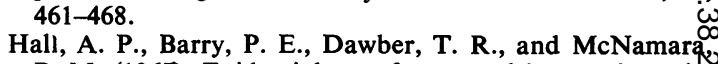
P. M. (1967). Epidemiology of gout and hyperuricaemia. American Journal of Medicine, 42, 27-37.

Howe, G. (1963). National Atlas of Disease and Mortality in the United Kingdom. Nelson: London.

Kellgren, J. H. (1964). The epidemiology of rheumatic diseases. Annals of the Rheumatic Diseases, 23, 109D 122.

Kellgren, J. H., Lawrence, J. S., and Aitken-Swan, J. (1953 Rheumatic complaints in an urban population. Annals the Rheumatic Diseases, 12, 5-15.

Lawrence, J. S. (1960). Heritable disorders of connective tissue. Proceedings of the Royal Society of Medicine, 5 W $522-526$

Lennane, G. A. Q., Rose, B. S., and Isdale, I. C. (1960弓 Gout in the Maori. Annals of the Rheumatic Diseases, 19 120-125.

Mikkelsen, W. M., Dodge, H. J., and Valkenburgh, $\stackrel{\mathbb{P}}{\mathrm{P}}$ (1965). The distribution of serum uric acid values in population unselected as to gout or hyperuricaemia American Journal of Medicine, 39, 242-251.

Office of Population Censuses and Surveys (1974). Morbidite Statistics from General Practice, 2nd National Study 1970-71. HMSO: London.

Popert, A. J., and Hewitt, J. V. (1962). Gout and hyperuri? caemia in rural and urban populations. Annals of the Rheumatic Diseases, 21, 154-163.

Population Projections 1974-2014. (1976). Office of PopuB lation Censuses and Surveys, Series PP2, No. 5, Appendi范 Table IVb, pp. 60-61. HMSO: London.

Rose, G. (1968). Variability of angina: Some implications of epidemiology. British Journal of Preventive and Sociats Medicine, 22, 12-15.

Sturge, R. A., Scott, J. T., Kennedy, A. C., Hart, D. P., an Watson, W. (1977). Serum uric acid in England and Scotland. Annals of the Rheumatic Diseases, 36, 420 427.

Traut, E. F. (1952). Rheumatic Diseases, p. 301. C. Mosby: London and New York.

World Health Statistics Annual (1976). Volume 1, Vited Statistics and Causes of Death, 1973-1976. Geneva.

Wyngaarden, J. B., Fredrickson, D. S. (1960). Metabol Basis of Inherited Disease, 1st edn., p. 679. McGrawHill: New York. 